\title{
Nurmikon leikkuun polttoainekulutus ja kasvihuonekaasupäästöt osana viherrakennuskohteen elinkaariarviointia
}

\author{
Frans Silvenius $^{1)}$, Aaro Alaspää ${ }^{2)}$, Oiva Niemeläinen ${ }^{2)}$ ja Kirsi Raiskio ${ }^{2)}$ \\ ${ }^{1}$ MTT BEL Latokartanonkaari 9, 00790 Helsinki \\ ${ }^{2}$ MTT KTL Planta, Tietotie, 31600 Jokioinen, 00790 Helsinki
}

\section{Tiivistelmä}

EU LIFE09 ENV FI 000570 "LCA in Landscaping" - hankkeessa mitattiin nurmikon leikkuukoneen polttoainekulutusta erilaisissa olosuhteissa kesällä 2012. Mittaukset tehtiin puistonurmikolla MTT:1lä Jokioisten toimipisteessä sekä Hämeenlinnassa Sairion puistoalueella. Mittatulosten perusteella laskettiin nurmikon leikkaamisen päästöt ja ilmastovaikutus eri leikkuuintensiteeteille. Leikkuuintensiteettejä olivat leikkuu viikoittain, leikkuu joka toinen viikko ja leikkuu 1 kerta kolmessa viikossa. Ilmastovaikutusta verrattiin muihin puistonurmikolla tehtävien hoitotoimenpiteiden (lannoittaminen ja kalkitus) aiheuttamaan ilmastovaikutukseen. Ilmastovaikutuksen lisäksi mitattiin ns. "hukka-ajon" ja polttoaineenkulutusta erimuotoisilla lohkoilla. Hukka-ajo (\%) ilmaisee, kuinka suuresta osasta leikattavaa lohkoa leikkuuyksikkö on kulkenut moneen kertaan. Hukka-ajomittauksia tehtiin Jokioisilla MTT:ssä, jonka lisäksi tehtiin täydentäviä mittauksia Hämeenlinnassa Sairion puistoalueella. Keskimääräinen polttoaineenkulutus Jokioisilla oli 4,2 1/ha bensiiniä ja työsuoritus noin $3400 \mathrm{~m}^{2} / \mathrm{h}$ ja Hämeenlinnassa 5,26 1 dieseliä/ha (Kuva 3) työsuorituksen ollessa $7300 \mathrm{~m}^{2} / \mathrm{h}$. Polttoaineenkulutus vaihteli runsaasti sekä samalla alueella että erialueilla tehdyissä mittauksissa. Verrattaessa nurmikon leikkuun ilmastovaikutuksia muihin nurmikon hoitotoimenpiteisiin havaittiin, että nurmikon leikkuun lisäksi suuri ilmastovaikutus on myös kalkituksella ja lannoituksella siten, että suurilla kalkitusmäärillä ja pienimmillä polttoaineenkulutuksen arvoilla kalkituksen ja lannoituksen osuus kasvihuonekaasupäästöistä on suurempi kuin ruohonleikkuun. Vastaavasti taas pienillä kalkitusja lannoitusmäärillä nurmikon leikkuun kasvihuonekaasupäästöt nousevat merkittävimmiksi. Tuloksista oli odotettavaa, että Hämeenlinnassa käytetyn suuremman leikkuukoneen työsuoritus oli suurempi kuin Jokioisilla käytetyn pienen koneen, mutta sitä, että pienemmän koneen pienempi hehtaarikohtainen polttoaineenkulutus oli yllättävä. Syyn arveltiin olevan pienemmän koneen pienemmässä painossa.

\section{Asiasanat}

Nurmikonleikkuun polttoaineenkulutus, elinkaariarviointi, ilmastovaikutus

\section{Johdanto}

Vuonna 2012 kaupunkien ja kuntien hoidettava puistoalue Suomessa oli 2,8 ha tuhatta asukasta kohti (tilastokeskus 2011) eli yhteensä noin 15000 ha. Jos oletetaan, että nurmikot niitetään keskimäärin 10 kertaa kasvukaudessa, niin niittoala vuodessa on yhteensä 150000 ha. Tutkimustietoa on saatavilla kuitenkin vähän puistoruohonleikkureiden polttoaineenkulutuksesta ja päästöistä. Tietoa tarvittaisiin nurmikon ylläpidon elinkaarilaskelmissa. Tässä artikkelissa, joka pohjautuu osittain Aaro Alaspään Helsingin yliopistossa tekemään maisterintutkielman tuloksiin 2013, Puistoruohonleikkurin polttoainekulutus ja kasvihuonekaasut sekä osittain EU LIFE09 ENV FI 000570 "LCA in Landscaping" - hankkeeseen, jossa tutkitaan puistoruohonleikkurin hehtaarikohtaisia polttoaineenkulutuksia sekä pyritään selvittämään pääasialliset siihen vaikuttavat tekijät. Lisäksi 
nurmikon leikkuun polttoaineenkulutuksia suhteutetaan muuhun nurmikon ylläpitoon liittyvään toimintaan, kuten lannoitukseen ja kalkitukseen. Muut osat nurmikon elinkaaresta, kuten kasvualustan valmistus ja nurmikkoalueen perustaminen jäävät tämän tarkastelun ulkopuolelle (Kuva 1), mutta niitä tutkitaan muissa osioissa LCA in landscaping-hanketta.

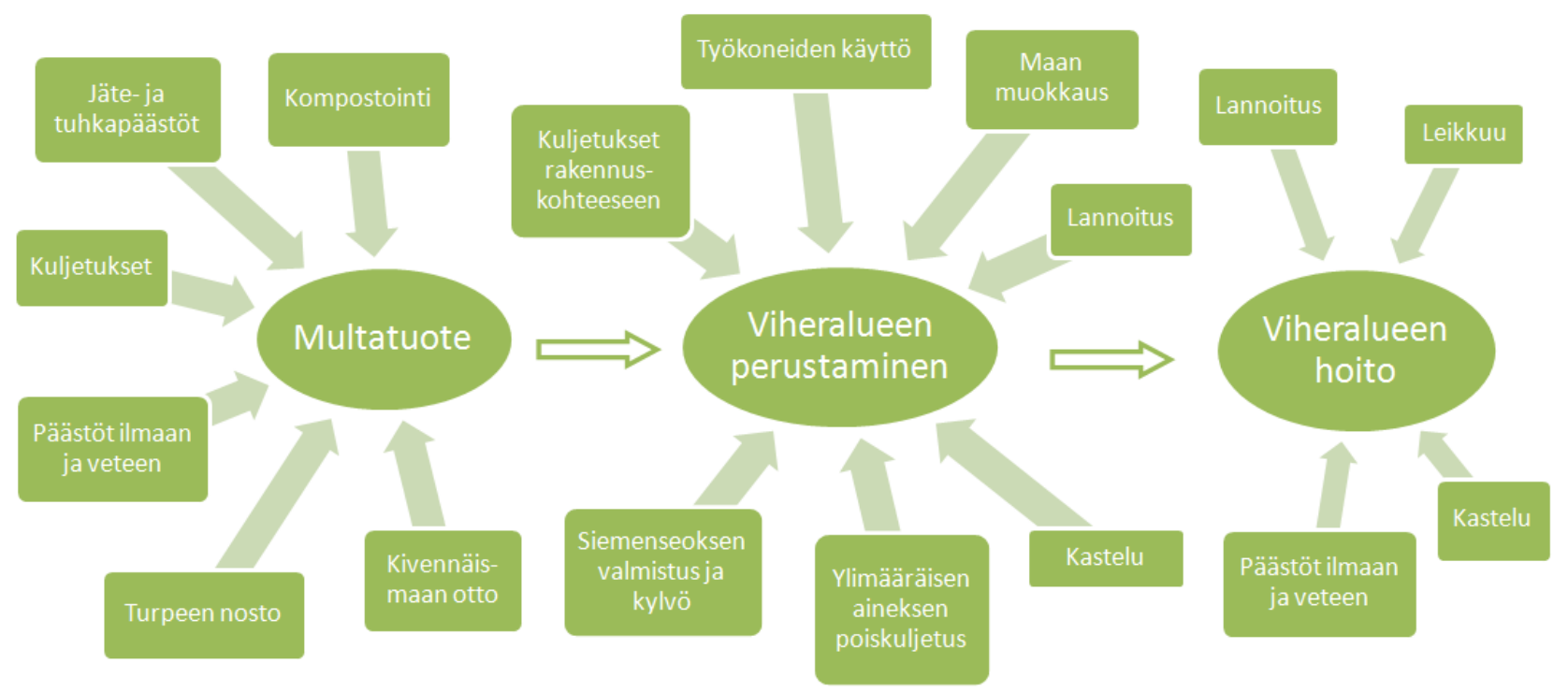

Kuva 1. Viheralueen elinkaaren toiminnot. Tässä artikkelissa käsitellään pelkästään viheralueiden hoitoa.

\section{Aineisto ja menetelmät}

Polttoaineenkulutusmittauksia tehtiin sekä MTT:1lä Jokioisten toimipisteessä puistonurmikolla että Hämeenlinnassa Hämeenlinnan kaupungin kanssa yhteistyössä Sairiossa sijaitsevalla puistoalueella. MTT:1lä Jokioisten toimipisteessä mittauksia tehtiin Husqvarna Rider 16 C ruohonleikkurilla, jonka leikkuuleveys oli $100 \mathrm{~cm}$ ja joka oli bensiinikäyttöinen ja Hämeenlinnassa Sairion puistoalueella John Deere 1445 diesel-ruohonleikkurilla, jonka työleveys oli $183 \mathrm{~cm}$. Jokioisten mittaustulosten perusteella laskettiin nurmikon leikkaamisen päästöt ja ilmastovaikutus eri leikkuuintensiteeteille. Leikkuuintensiteettejä olivat leikkuu viikoittain, leikkuu joka toinen viikko ja leikkuu 1 kerta kolmessa viikossa. Ilmastovaikutusta verrattiin muihin puistonurmikolla tehtävien hoitotoimenpiteiden (lannoittaminen ja kalkitus) aiheuttamaan ilmastovaikutukseen. Ilmastovaikutuksen lisäksi mitattiin ns. "hukka-ajo" ja polttoaineenkulutusta eri muotoisilla lohkoilla. Hukka-ajo (\%) ilmaisee, kuinka suuresta osasta leikattavaa lohkoa leikkuuyksikkö on kulkenut moneen kertaan. Hukka-ajomittauksia tehtiin Jokioisilla MTT:1lä, jonka lisäksi tehtiin täydentäviä mittauksia Hämeenlinnassa Sairion puistoalueella John Deere 1445 diesel-ruohonleikkurilla, jonka työleveys oli $183 \mathrm{~cm}$. Työsuorituksen dokumentointiin ja hukka-ajon todentamiseen käytettiin GPS-laitetta, jolla saatiin laskettua ruohonleikkurin leikkuun avulla kulkema kokonaismatka. Mittauksia tehtiin Jokioisten kohteella samalla alueella kuusi kertaa kesän aikana ja Sairiossa saman päivän aikana neljällä eri alueella.

Ruohonleikkuriin kiinnitetyn GPS -laitteen ( Trimple Pro XH) ja tietokoneohjelmien (ArcGIS) avulla laskettiin ajomatkat sekä käytetty aika ja näin pystyttiin selvittämään muodostunutta hukka-ajoa. Nurmikoissa käytettävän siemenseoksen vaikuttavuutta leikkuukertojen määrään tutkittuun myös. Hypoteesina oli, että leikkuukertoja vähentämällä sekä ajolinjojen tarkalla suunnittelulla voidaan vaikuttaa polttoaineen kulutukseen sekä tätä kautta päästöjen määrään. Nurmikon leikkuun ilmastovaikutusta verrattiin muihin puistonurmikolla tehtävien hoitotoimenpiteiden (lannoittaminen ja kalkitus) aiheuttamaan ilmastovaikutukseen. Polttoaineen kulutukseen vaikuttavista tekijöistä tutkittiin $\mathrm{mm}$. polttoaineenkulutusta suhteessa nurmikon pituuteen ja kosteuteen. Lannoituksen ilmastovaikutuksena käytettiin arvoa 3,6kgCO2-ekv/kg N (Yara 2012) ja dityppioksidin päästökerroin lannoitustason suhteen laskettiin käyttämälä Reginan ym. (2013) päästökertoimia. 


\section{Tulokset}

Keskimääräinen polttoaineenkulutus Jokioisten leikkuukokeessa oli 4,2 1 bensiiniä/ha (Kuva 2) ja työsuoritus noin $3400 \mathrm{~m}^{2} / \mathrm{h}$ ja Hämeenlinnassa taas 5,26 1 dieseliä/ha (Kuva 3) työsuorituksen ollessa7300 $\mathrm{m}^{2} / \mathrm{h}$. Vuonna 2012 Jokioisten mittausten polttoaineenkulutus samalla suorakaiteenmuotoisella ja esteettömällä leikkuualueella vaihteli välillä 3,3 l/ha ja 5,3 1/ha nurmikon korkeuden vaihdellessa välillä 4,7ja $8,3 \mathrm{~cm}$. Leikkuukorkeus oli joka kerralla $5 \mathrm{~cm}$. Leikattu biomassa vaihteli välillä $398 \mathrm{~kg}$ ja $825 \mathrm{~kg}$ ja kosteus väillä 67,4 \% ja 75,7\%. Yhteensä kuuden leikkuukerran polttoaineenkulutus oli 23 1/ha.

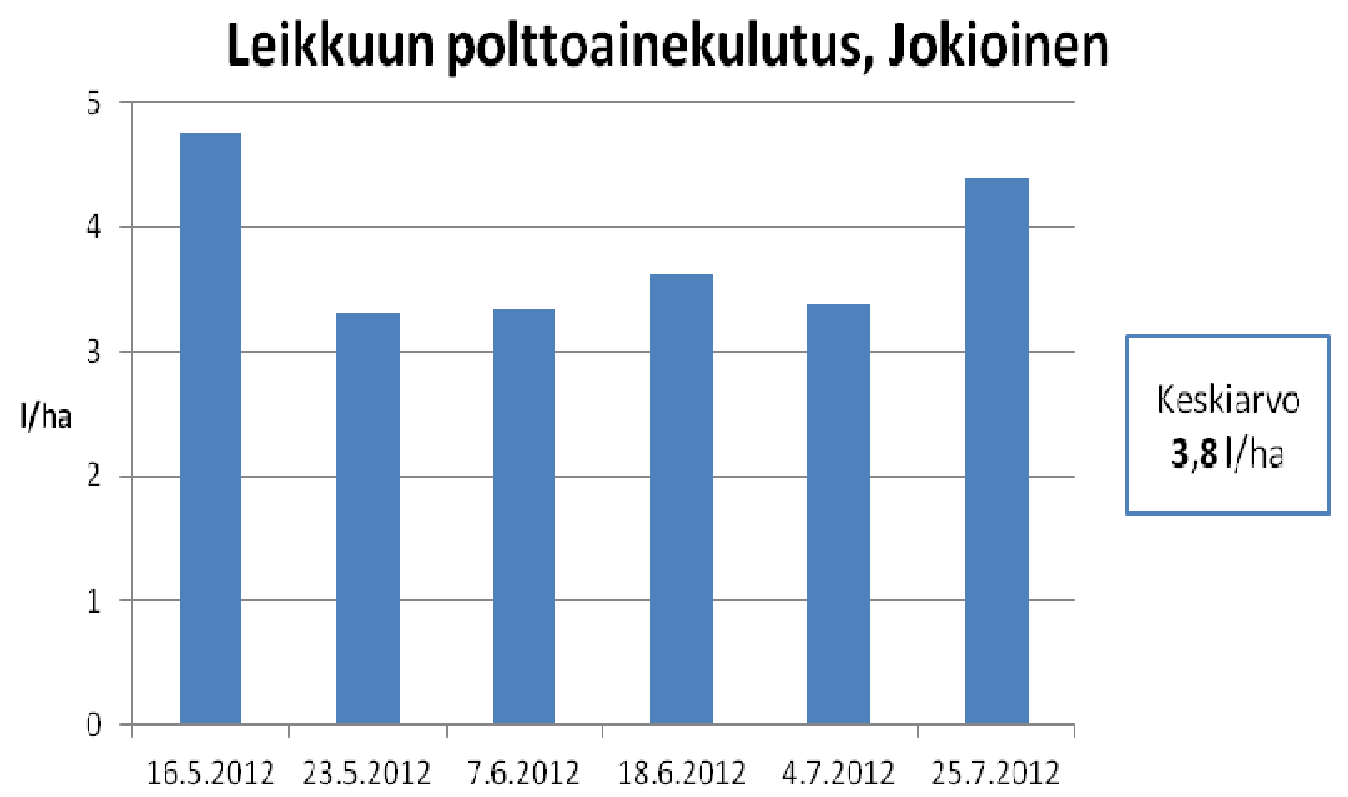

Kuva 2. nurmikon leikkuun polttoaineenkulutus Jokioisten mittauskokeissa kesällä 2012. Polttoaine bensiini.

\section{Leikkuun polttoainekulutus, Sairio 12.9.2012}

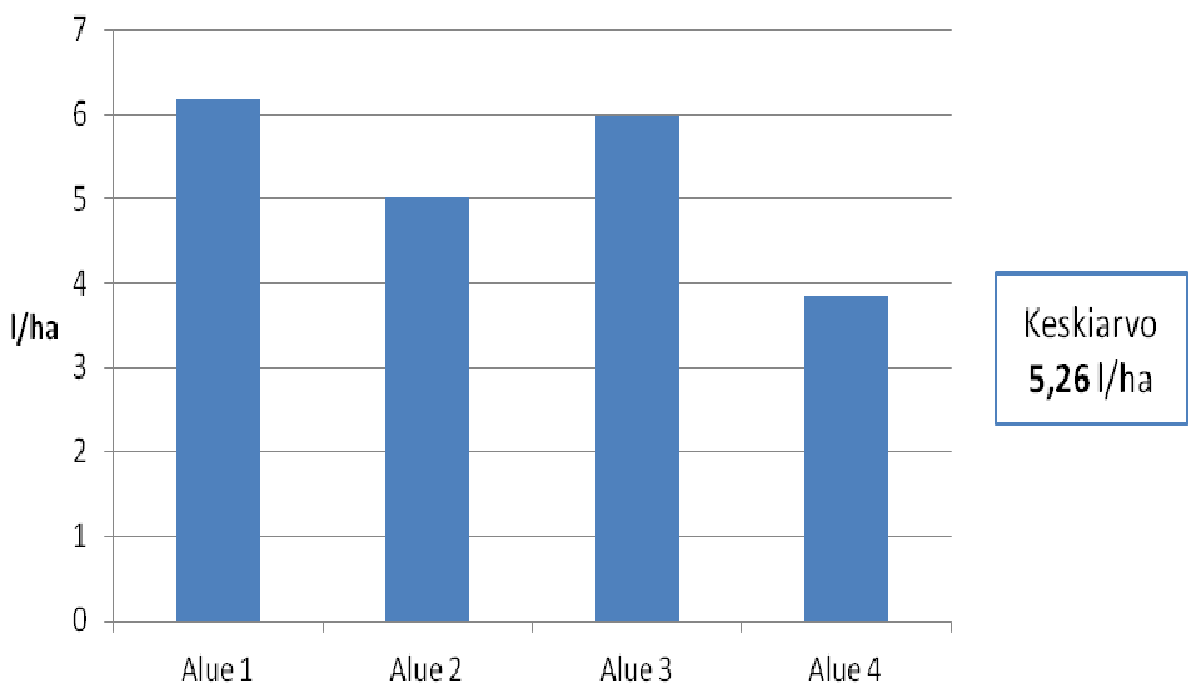


Kuva 3. Nurmikon leikkuun polttoaineenkulutus Sairion mittauskokeessa Hämeenlinnassa kesällä 2012. Polttoaine dieselöljy.

Nurmikon kosteuden ja nurmikon leikkaamisen polttoaineen kulutuksen välinen riippuvuus oli tulosten mukaan heikko $(\mathrm{r}=0,55)$ eikä se ollut tilastollisesti merkitsevä $(\mathrm{p}=0,44)$. Kasvuston pinnalla ei ollut irtovettä. Kasvusto oli tuoretta verrattuna säilörehuksi korjattavan kasvuston kuivaainepitoisuuteen (Sipilä 2006). Nurmikon mittatikulla mitatun leikkutta edeltävän korkeuden ja kuluneen polttoaineen väillä oli sen sijaan lineaarinen riippuvuus. Päästölaskentaa varten tuloksista pääteltiin, että mittatikulla mitattuna $11 \mathrm{~cm}: n$ leikkuukorkeudella polttoainetta kului $2,7 \mathrm{~kg} / \mathrm{ha}, 15$ cm:n korkeudella 2,9 kg/ha ja $19 \mathrm{~cm}$ :n korkeudella $3,7 \mathrm{~kg} / \mathrm{ha}$. Tuloksista pystyttiin päättelemään, että ruohonleikkuun ilmastovaikutukset voidaan lähes puolittaa, jos leikkuukertoja saadaan vähennettyä viikon välisestä leikkuusta 2 viikon välein tapahtuvaan leikkuuseen, mutta kolmen viikon välein tapahtuvan leikkuun ero kahden viikon välein tapahtuvaan leikkuuseen oli pieni . taulukko 8. Tämä on mahdollista käyttämällä hidaskasvuisempia nurmikkoseoksia

"Hukka-ajo" laskettiin tutkimuksessa käyttämällä hyväksi ajon aikana kerättyä GPS-dataa. Hämeenlinnan Sairion puistoalueen mittauspaikat esitetty kuvassa 4. Ensimmäisellä leikkuukerralla hukka -ajoa oli $71 \%$ ja toisella kerralla $71 \%$. Ensimmäisellä leikkuukerralla perutuksia oli 2,3\% kokonaismatkasta ja toisella kerralla 3,1\% kokonaismatkasta, eli siis hyvin vähän. Sairion alueilla hukka-ajon määrä vaihteli 25 ja 88 \%:n välillä. Aikaisemmissa tutkimuksissa (Peltola ym. 1979) on todettu, että lohkon kolmiomainen muoto ja pieni koko voivat lisätä työnmenekkiä ja polttoaineenkulutusta $40 \%$ peruslohkoon verrattuna. Esimerkkinä edullisesta lohkosta mainittakoon Sairion lohko 3, mikä on pitkä ja kapea ja alaltaan 0,18 m2. Hukka-ajotutkimuksen GPS-mittaukset Sairion lohkon osalta ja tulokset hukka-ajotutkimuksesta on esitetty taulukossa 1. 


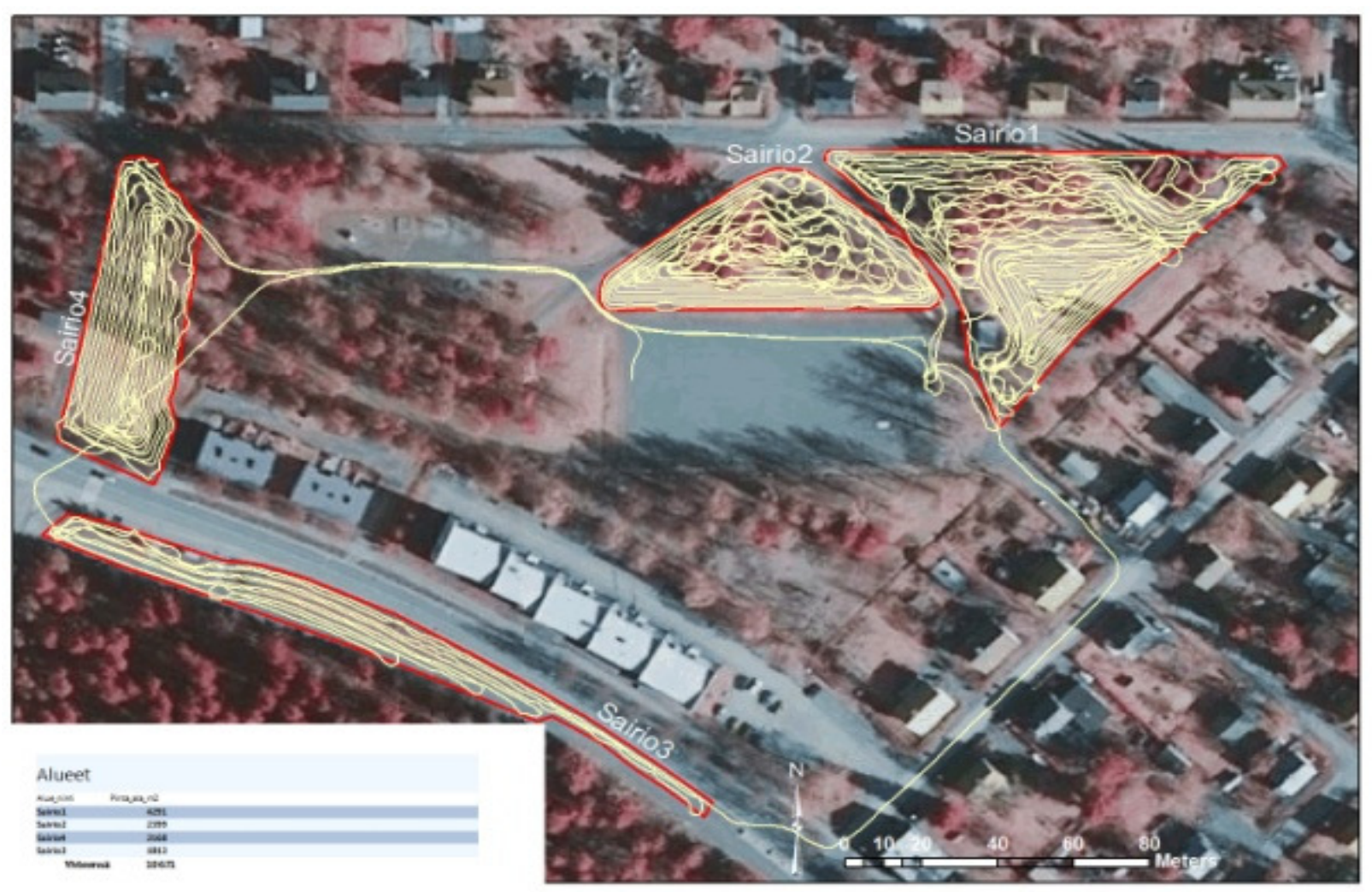

Kuva 4. Hämeenlinnan Sairion puistoalueen neljä mittauspaikkaa.

Taulukko 1. Hämeenlinnan leikkuukoneen pinta-alat, kuljetut matkat ja hukka-ajo-\%.

\begin{tabular}{|l|l|l|l|}
\hline Leikkuualue & Matka (m) & Digitoitu ala (ha) & Hukka - ajo ( \%) \\
\hline Sairio 1 & 3910 & 0,43 & 71 \\
\hline Sairio 2 & 2464 & 0,23 & 88 \\
\hline Sairio 3 & 1243 & 0,18 & 25 \\
\hline Sairio 4 & 1968 & 0,22 & 66 \\
\hline
\end{tabular}

Nurmikon leikkuun vuosittaisten kasvihuonekaasupäästöjen vertailuissa havaittiin, että kalkituksen ja lannoituksen yhteenlasketut kasvihuonekaasupäätöt saattavat nousta jossain tapauksissa suuremmiksi kuin nurmikon leikkuusta aiheutuvat kasvihuonekaasupäästöt. Näin kävisi Jokioisten kokeiden kesimääräisellä polttoaineenkulutuksella ja ylläpitokalkituksella $3000 \mathrm{~kg} / \mathrm{ha}$ viiden vuoden välein lannoitustason ollessa $100 \mathrm{~kg} / \mathrm{ha}$ keväällä. 


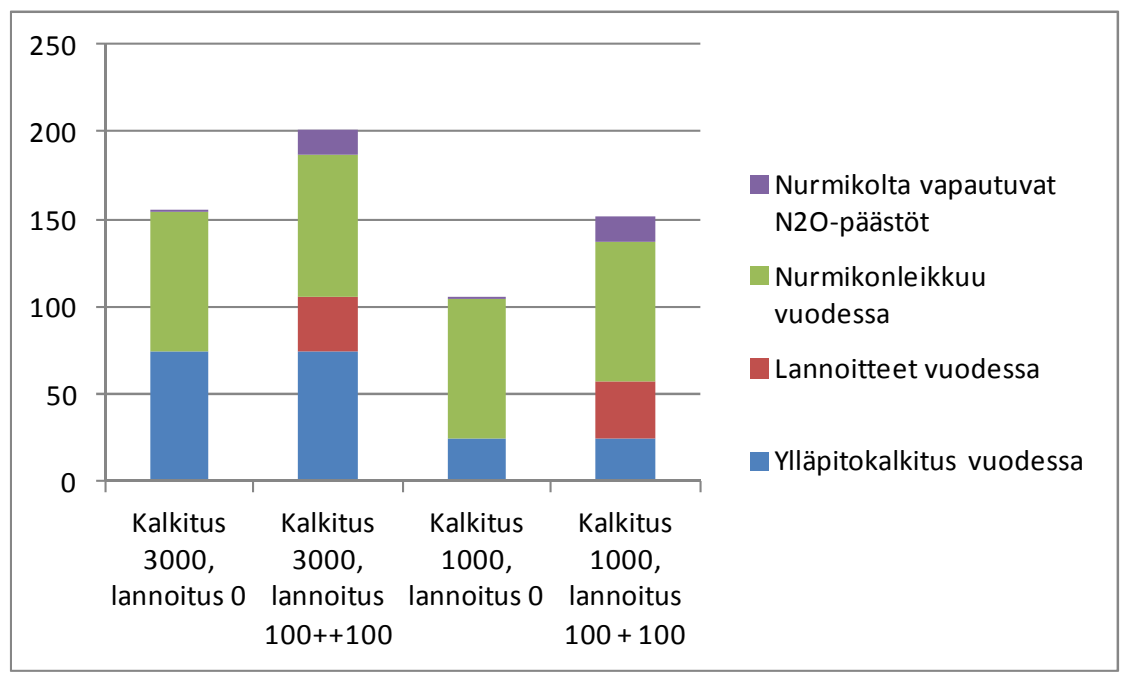

Kuva 5. Nurmikon leikkuun ilmastovaikutus verrattuna kalkituksen ja lannoituksen ilmastovaikutukseen ylläpitokalkituksilla 1000 kg/ha viidessä vuodessa ja 3000 kg/ha 100 kg NPK 9-3-12 keväällä

Mittauksissa ei otettu huomioon viherlaitoksen varikolta nurmikkoalueelle ja nurmikkoalueiden välillä tarvittavan siirtoajon polttoaineenkulutusta. Se voi olla sekä huomattava polttoaineenkulutus- että kustannustekijä. Suurten laitteiden leikkuuteho työtuntia kohti on huomattavasti suurempi kuin pienten laitteiden teho. Jos työkohde tekee vaikeaksi hyödyntää tehokkaasti laitteen leveää työleveyttä niin suuri osa työsuorituksesta voi olla ns. hukka-ajoa. Polttoaineenkulutuksessa Jokioisten kokeen pienen bensiinikäyttöisen ruohonleikkurin hehtaarikohtainen polttoaineenkulutus oli pienempi kuin suuremman bensiinikäyttöisen ruohonleikkurin Hämeenlinnan kokeessa. ). Polttoaineenkulutusta eri kohteissa ja siirtoajan määrän vaikutus selvitetään vuoden 2014 aikana.

\section{Johtopäätökset}

Eräs tärkeä tulos tässä kokeessa oli se, että nurmikon leikkuun polttoaineenkulutus vaihtelee varsin suuresti 1/ha. Vaihtelua tuli sekä saman alueen eri ajankohtina tapahtuvalla leikkuulla että kokeessa jossa leikattiin useita eri alueita. Tässä selvityksessä suuren laitteen polttoaineenkulutus 1/ha oli suurempi kuin keskikokoisen laitteen. Eräs selitys voisi olla se, että laitteen suurempi paino johtaa suurempaan polttoaineen kulutukseen. Tämä selittäisi silloin näiden kokeiden tuloksia, joissa siis pieni leikkuri kuluttaisi vähemmän polttoainetta kuin suuri. Toisaalta näiden kokeiden aineisto on sen verran suppea, että yleispätevää johtopäätöstä leikkurin koon vaikutuksesta polttoaineenkulutukseen ei pysty tekemään. Kustannustekijöitä ajateltaessa suurella leikkurilla päästään parempaan työsuoritteeseen, eli tuntikohtainen leikkuuala on suurempi kuin pienemmällä leikkurilla, mikä taas vaikuttaa palkkauskustannuksiin

Hukka-ajon määrä nurmikkolohkolla voi olla huomattavan suuri, ja tässä tapauksessa Hämeenlinnan kokeessa vaihtelua oli välillä 25-88 \%..Aineistosta ei kuitenkaan saatu laskettua yhteyttä hukka-ajon ja hehtaarikohtaisen polttoaineenkulutuksen välillä. Yksi tärkeä tutkimustulos oli myös se, että tutkimuksia polttoaineen kulutuksesta erikokoisilla laitteilla ja ml. myös siirtoajot on tarpeen jatkaa, sillä siirtoajon osuus nurmikonleikkuun polttoaineenkulutuksista voi olla huomattava. Lisäksi tutkimus osoitti sen, että pääsääntöisesti nurmikon leikkuusta aiheutuvat kasvihuonekaasupäästöt ovat pääsääntöisesti suurin yksittäinen tekijä nurmikon hoitovaiheenkasvihuonekaasupäästöjä mitattaessa. Kuitenkin lannoitteiden ja kalkin käytöstä ja valmistuksesta aiheutuvat yhteenlasketut kasvihuonekaasupäästöt voivat suurilla kalkitusmäärillä olla suuremmat kuin vastaavat nurmikon leikkuusta aiheutuvat päästöt. LCA in landscaping-hankkeessa tutkitaan edelleen sitä, mitkä ovat kasvualustan tuotannon ympäristövaikutukset nurmikon leikkuun ympäristövaikutuksiin nähden. Koska kasvualustoja tarvitaan suuria määrä, on hankkeen alustavissa tuloksissa havaittu, että tutkittaessa puistonurmikon koko elinkaarta, on kasvualustan elinkaaren merkitys keskeinen. Tutkimuksia polttoaineen kulutuksesta erikokoisilla laitteilla myös siirtoajojen polttoaineenkulutusta 
on tarpeen jatkaa, sillä siirtoajon osuus nurmikonleikkuun polttoaineenkulutuksista voi olla huomattava.

\section{Kirjallisuus}

Alaspää, A. 2013. Puistoruohonleikkurin polttoainekulutus ja kasvihuonekaasupäästöt. Maisterintutkielma, Helsingin yliopisto, Maataloustieteiden laitos, Maatalous- ja ympäristöteknologia. 20.9.2013.

Peltola, A.,. Orava, R. Oksanen, E. 1979. Lohkon koon ja muodon vaikutus peltotöiden työnmenekkiin. Työtehoseura, Helsinki.

Regina, K., Kaseva, J. and Esala, M. (2013) Emissions of nitrous oxide from boreal agricultural mineral soils statistical models based on measurements. Agriculture, Ecosystems \& Environment.164(1)131-136

Solomon, S., Qin, D., Manning, M., Alley, R.B., Berntsen, T., Bindoff, N.L., Chen, Z., Chidthaisong, A., Gregory, J.M., Hegerl, G.C., Heimann, M., Hewitson, B., Hoskins, B.J., Joos, F., Jouzel, J., Kattsov, V., Lohmann, U., Matsuno, T., Molina, M., Nicholls, N., Overpeck, J., Raga, G., Ramaswamy, V., Ren, J., Rusticucci, M., Somerville, R., Stocker, T.F., Whetton, P., Wood, R.A. ja Wratt, D. 2007. Technical Summary. In: Climate Change 2007: The Physical Science Basis. Contribution of Working Group I to the Fourth Assessment Report of the Intergovernmental Panel on Climate Change. Cambridge University Press, Cambridge. Pp. 19-91

Yara 2012. Hiilijalanjälki. Saatavana verkossa: http://www.yara.fi/sustainability/climate/index.aspx luettu 31.3.2013 